American Journal of Biochemistry and Biotechnology 6 (2): 111-115, 2010

ISSN 1553-3468

(C) 2010 Science Publications

\title{
Tailor-Made Enzyme Carriers: Preparation and Use of Adsorbents Specifically Designed to Immobilize Allosteric Enzymes in Activated Conformation
}

\author{
Zahra Salemi \\ Institute of Biochemistry and Biophysics, University of Tehran, \\ P.O. Box 1314-1384, Tehran, Iran \\ Department of Biochemistry, Arak University of Medical Sciences, Arak, Iran
}

\begin{abstract}
Problem statement: The enzyme immobilization has experienced substantial growth in the recent past and an ever increasing amount of study has been reported on various aspects of immobilized enzymes. In most of these investigations, catalytic activities are found to be diminished as compared to the enzyme free in solution. Approach: Hydrophobic adsorbents were prepared containing L-leucine or citric acid, two positive allosteric effectors, for bovine liver Glutamate Dehydrogenase (GDH, EC 1.4.1.3) and heart mitochondrial Malate Dehydrogenase (MDH, EC 1.1.1.37 ), respectively. Results: Immobilized preparations of these well-defined allosteric enzymes indicated improved catalytic activities as compared with those involving use of the adsorbents without these activators. Conclusion/Recommendations: It is concluded that the regulatory proteins are Furthermore; they retain their natural capacity for undergoing the conformational transitions needed for enhanced catalytic activities. Adsorptive immobilization of these two allosteric proteins in activated conformation may serve as useful models in relation to design strategies for preparation of tailor-made enzyme carriers.
\end{abstract}

Key words: Glutamate Dehydrogenase (GDH), Malate Dehydrogenase (MDH), allosteric enzymes, activated conformation, adsorptive immobilization, hydrophobic matrix

\section{INTRODUCTION}

The science and technology of enzyme immobilization have experienced substantial growth in the recent past and an ever increasing amount of study has been reported on various aspects of immobilized enzymes. In most of these investigations, catalytic activities are found to be diminished as compared to the enzyme free in solution.

Our own previous studies involving use of hydrophobic supports indicated the possibility of protein adsorption with retention of native properties (NematGorgani and Karimian, 1982; 1983; 1984; 1986; NematGorgani et al., 1985). In such studies, bovine liver glutamate dehydrogenase was used as a model allosteric protein and the immobilized preparation was found to retain its response to all of the relevant allosteric modifiers tested, including L-leucine, in addition to retaining its usual catalytic activities. This was taken to suggest that interaction may occur between specific residues on the protein, not directly related to its catalytic or allosteric properties. Furthermore, flexibility of protein structure is maintained and the heterotropic allosteric conformational changes may take place upon interaction of the immobilized enzyme with the effectors.
The present communication describes use of two different preparations of octyl Fractosil containing Lleucine or citrate, as positive allosteric effectors for bovine liver glutamate dehydrogenase and porcine heart mitochondrial malate dehydrogenase, respectively. Results indicate that these regulatory enzymes may be immobilized on the adsorbents while retaining their capacity for interaction with the activators and the tendency to undergo the required conformational changes leading to enhanced catalytic activities.

\section{MATERIALS AND METHODS}

Fractosil 500 (Art 15707) and all chemicals of the highest purity available were purchased from Merck (Germany). All biochemicals were obtained from Sigma (St. Louis, MO, USA). Reproducibility of the data presented in this manuscript was confirmed by repeating the experiments at least twice.

Synthesis of octadecanol containing l-leucine: Oleyl alcohol was first converted to its epoxide derivative, 9, 10-epoxyoctadecanol, about $4 \mathrm{~g}(0.013 \mathrm{~mol})$ of this material was then treated with $1.75 \mathrm{~g}(0.013 \mathrm{~mol})$ of Lleucine in the presence of sodium ethoxide in ethanol 
essentially according to the procedure described by Sidelkovskaya et al. (1986). The mixture was refluxed for $3 \mathrm{~h}$ and was then added to ice-water $(500 \mathrm{~mL})$. About 9-(10)-Leucyl-10(9)-hydroxyoctadecane-1-ol was obtained as a white precipitate which was then recrystallized from ethanol $(72 \%), \quad m p=41-42{ }^{\circ} \mathrm{C} .{ }^{1} \mathrm{H}$ NMR $\left(\mathrm{CDCl}_{3}\right)$ : d 0.8-1.7 (br. s., $40 \mathrm{H}, \mathrm{CH}_{3}, \mathrm{CH}_{2}$ ), 2 (br. s., 4H, $2 \mathrm{OH}, \mathrm{N} \underline{\mathrm{H}}, \mathrm{COO} \underline{\mathrm{H}}$ ), 3.1-3.7 (br. s., $\mathrm{C}_{2} \mathrm{OH}$, $\mathrm{CHOH}$ ). IR (nujol): 3600-3000 (COOH, NH, OH), $1750(\mathrm{C}=\mathrm{O}), 920(\mathrm{OH}$, out of plane $) \mathrm{cm}^{-1}$.

Synthesis of octadecanol containing citrate: About $2.16 \mathrm{~g}$ (0.01 mol) 9, 10-epoxyoctadecanol and $1.92 \mathrm{~g}$ (0.01 mol) citric acid were mixed with DMF $(20 \mathrm{~mL})$ and the mixture was heated at $100^{\circ} \mathrm{C}$ for $8 \mathrm{~h}$. The reaction mixture was cooled and mixed with $100 \mathrm{~mL}$ ethyl acetate. The mixture was washed with $5 \times 30 \mathrm{~mL}$ water, dried with sodium sulfate, filtered and the solvent was evaporated. An oily solid compound was obtained which was then crystallized from methanol $(80 \%) \mathrm{mp}=39-40^{\circ} \mathrm{C}$. ${ }^{1} \mathrm{H} \mathrm{NMR}\left(\mathrm{CDCl}_{3}\right)$ : $0.8-1.5$ (br. s., $31 \mathrm{H}, \mathrm{CH}_{3}, \mathrm{CH}_{2}$ ), 2.7 (s., $4 \mathrm{H}, \mathrm{CH}_{2}-\mathrm{COOH}$ ), 3.2-3.8 (br. s., $4 \mathrm{H}, \mathrm{C}_{2} \mathrm{OH}, \mathrm{C} \underline{\mathrm{HOH}}, \mathrm{C} \underline{\mathrm{HO}}$ ), 4.5 (br. s., $1 \mathrm{H}$, $\mathrm{OH}$ ), 11 (br. s., $3 \mathrm{H}, \mathrm{COO} \underline{\mathrm{H}}$ ). IR (nujol): $3600-3000$ (COOH, OH), $1750(\mathrm{C}=\mathrm{O}), 1040(\mathrm{C}-\mathrm{O}), 920$ (OH, out of plane) $\mathrm{cm}^{-1}$.

Preparation of derivatized Fractosil: This was carried out exactly as described previously (Nemat-Gorgani and Karimian, 1986). The alkyl chains, with or without the allosteric effector, were used for preparation of the hydrophobic adsorbents (Fig. 1).

$\mathrm{X}$ represents palmityl groups with or without the allosteric effectors which may be positioned on carbon 9 or 10 of the alkyl residues.

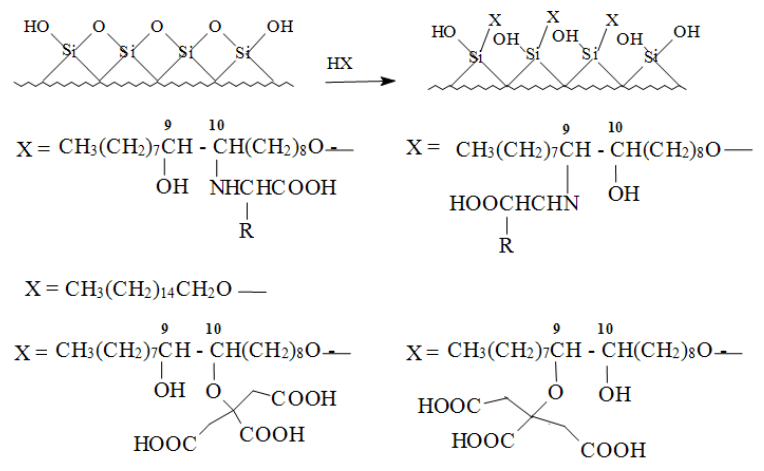

Fig. 1: X represents palmityl groups with or without the allosteric effectors which may be positioned on carbon 9 or 10 of the alkyl residues
Determination of the catalytic activity of GDH: Free GDH was assayed exactly as described previously (Nemat-Gorgani and Karimian, 1982). For determination of the activity of the immobilized enzyme, a procedure essentially as described previously (Azari and Nemat-Gorgni, 1999) was followed. The required amount of the matrix, washed twice with $0.1 \mathrm{~m}$ phosphate buffer containing $0.2 \mathrm{~mm}$ EDTA, pH 8.0 was added to an amount of GDH diluted in the same buffer. After mixing the suspension for $30 \mathrm{~min}$, washing was repeated two to three times to determine any unbound activity. The suspension was then transferred to $20 \mathrm{~mL}$ of GDH assay mix in a small beaker placed on a magnetic stirrer. At each $30 \mathrm{sec}$. interval, with continuous mixing, $1 \mathrm{ml}$ of the suspension was centrifuged, each time in a $1 \mathrm{~mL}$ cuvette for $1 \mathrm{~min}$ and the clear supernatant was immediately read at $340 \mathrm{~nm}$. Compared with other attempted procedures, this provided a convenient and reproducible method.

In comparing the catalytic activities of the enzyme immobilized on octadecyl Fractosil and octadecyl Fractosil containing L-leucine, $250 \mathrm{mg}$ of the matrix and $250 \mu \mathrm{g}$ of the enzyme were used. After binding, no activity could be detected in the supernatants provided from the washing steps described above. This indicated that the entire enzyme was immobilized and the two adsorbents, with and without L-Leucine, contained the same amount of the biocatalyst.

Determination of the catalytic activity of MDH: Free $\mathrm{MDH}$ was assayed in the $\mathrm{NAD}^{+} \rightarrow \mathrm{NADH}$ direction exactly as reported previously (Mullinax et al., 1982). To determine the activity of the immobilized enzyme, $20 \mu \mathrm{L}$ of an enzyme solution $\left(125 \mu \mathrm{g} \mathrm{mL}^{-1}\right)$ was added to $125 \mathrm{mg}$ of the matrix previously washed (three times) with $0.1 \mathrm{M}$ phosphate buffer, $\mathrm{pH} 6.0$, in a final volume of $0.5 \mathrm{~mL}$. The suspension was mixed for 30 min while on ice. Upon centrifugation, washing of the pellet was carried out twice. To the final pellet, $3 \mathrm{~mL}$ of the $\mathrm{MDH}$ reaction mixture was added and the procedure described for GDH was followed to determine the rate of $\mathrm{NAD}^{+}$reduction. Again, the two adsorbents, with and without the effectors, had the same enzyme content.

\section{RESULTS}

Use of octadecyl groups containing L-leucine: Octadecyl Fractosil containing L-leucine in the middle of alkyl chain (Fig. 1) was used to immobilize glutamate dehydrogenase. In a parallel experiment, the enzyme was immobilized on octadecyl Fractosil without L-leucine. Results of a typical experiment are 
presented in Fig. 2. As shown, an enhanced catalytic activity of the allosteric protein was obtained using the hydrophobic matrix containing L-leucine, presumably as a result of the effector interacting with the protein at its allosteric site.

Use of octadecyl groups containing D-leucine: The above experiment was repeated exactly except that the matrix contained D-leucine instead of L-leucine. As shown in Fig. 3, an appreciably lower activity was obtained in this case. In a parallel experiment, the two enantiometric forms of the amino acid were tested using free enzyme. The differences in the effectiveness of these isomers, as activators for the soluble enzyme, were comparable with results obtained using the immobilized form.

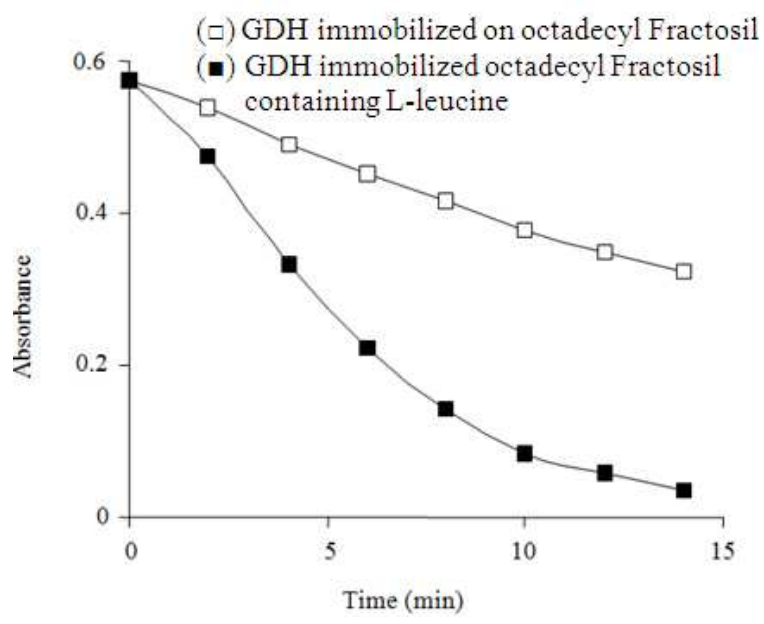

Fig. 2: Catalytic activity of immobilized GDH. $250 \mathrm{mg}$ of the matrix and $250 \mu \mathrm{g}$ of the enzyme were used

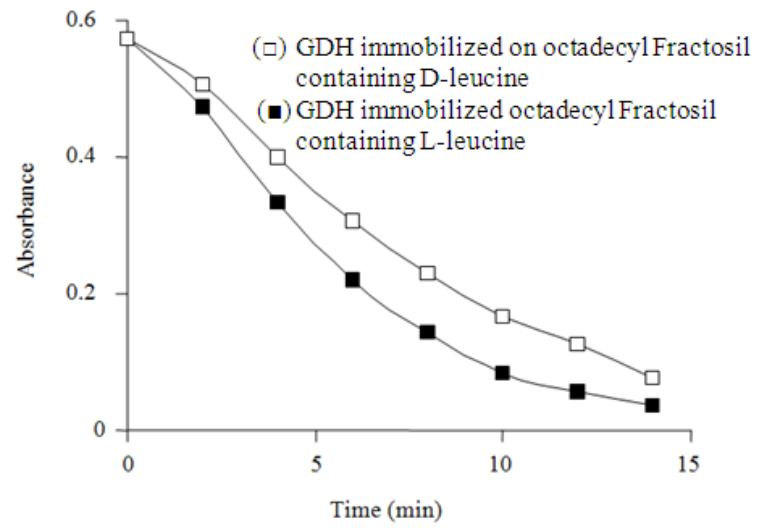

Fig. 3: Catalytic activity of immobilized GDH
Use of octadecyl groups containing L-alanine: In another control experiment, L-alanine was placed in the middle of the alkyl chain and the derivatized ligand was used to prepare the hydrophobic matrix. As expected, no enhancement of activity was observed.

Use of octadecyl groups containing citrate: The native form of porcine heart mitochondrial malate dehydrogenase is a dimmer of two identical $35 \mathrm{kDa}$ subunits. The enzyme has been shown to be specifically activated by citrate in the $\mathrm{NAD}^{+} \rightarrow \mathrm{NADH}$ direction (Mullinax et al., 1982). It has been proposed that citrate is bound to a regulatory site that is distinct from the catalytic site (Mullinax et al., 1982) and that the subunits are independently capable of allosteric regulation (Du Val et al., 1985).

In this part of the study, octadecyl Fractosil containing citrate (Fig. 1) was used to immobilize malate dehydrogenase and results of a typical experiment are presented in Fig. 4. As indicated, use of the hydrophobic matrix containing this activator resulted in enhancement of catalytic activity suggesting interaction of the effector with the enzyme at its allosteric site.

Effect of pH: Catalytic activities of GDH and MDH immobilized on adsorbents containing their respective activators were tested at various $\mathrm{pH}$ values (Fig. 5). In the $\mathrm{pH}$ values tested, higher activities were obtained using immobilized preparations containing alkyl groups substituted with the effectors, as compared with those containing unsubstituted alkyl chains. Furthermore, the overall shapes of the respective curves are quite similar.

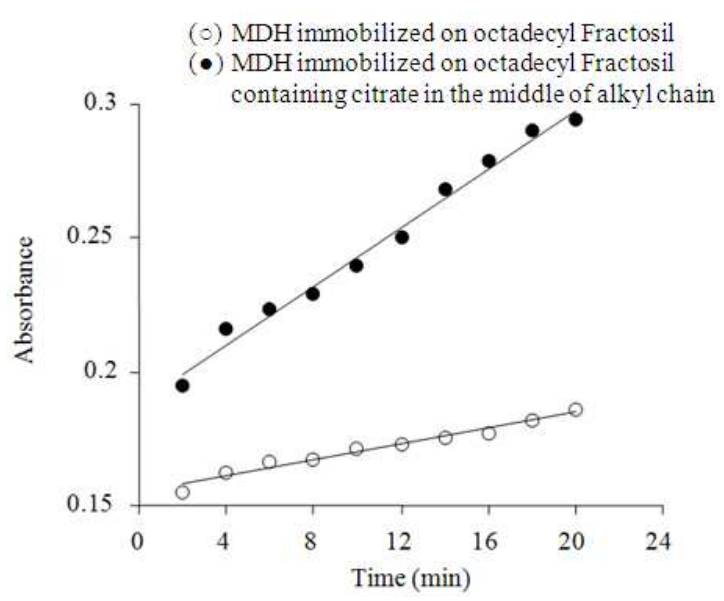

Fig. 4: Catalytic activity of immobilized MDH. $125 \mathrm{mg}$ of the matrix and $2.5 \mu \mathrm{g}$ of the enzyme were used 


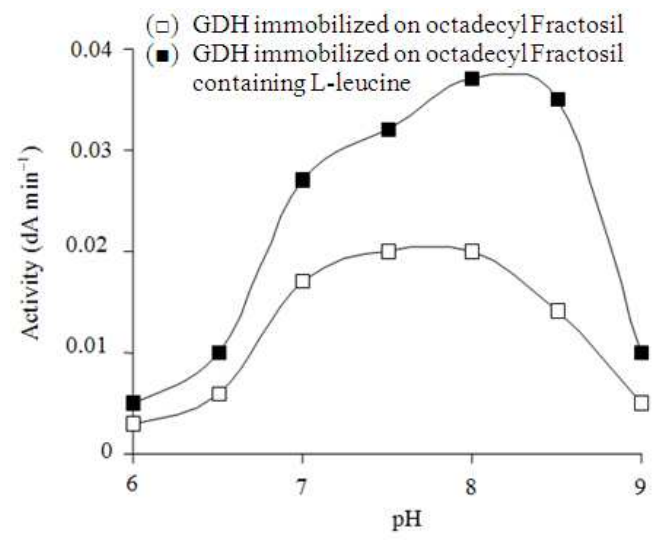

(A)

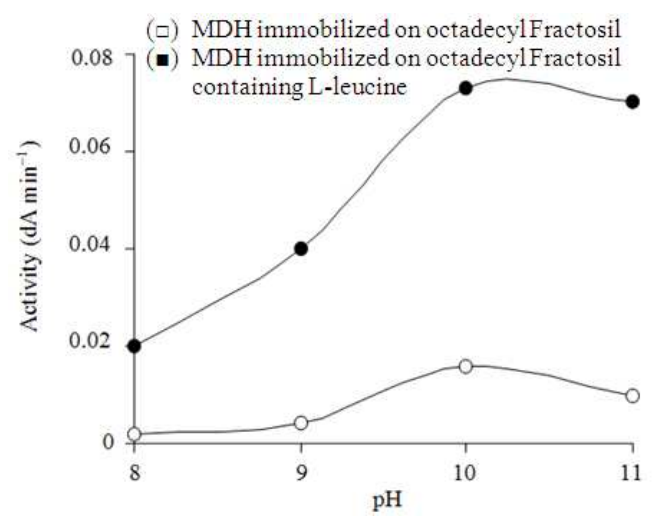

(B)

Fig. 5: (A) Effect of $\mathrm{pH}$ on the activity of immobilized GDH about $125 \mathrm{mg}$ of the matrix and $100 \mu \mathrm{g}$ of GDH were used. The buffer mix contained 0.04 M Pipes, $0.04 \mathrm{M}$ Hepes, $0.04 \mathrm{~m}$ Tris and all the required components for enzyme activity. (B) Effect of $\mathrm{pH}$ on the activity of immobilized $\mathrm{MDH}$. About $80 \mathrm{mg}$ of the matrix and $1.25 \mu \mathrm{g}$ of MDH were used. The buffer mix contained $0.035 \mathrm{~m}$ glycine, $0.035 \mathrm{~m}$ Mes, $0.035 \mathrm{~m}$ Tris and all the required components for enzyme activity

\section{DISSCUSION}

It is now generally accepted that the kinetic behavior of an enzyme attached to a surface may deviate from that observed when used free in solution, normally leading to reduced catalytic activities. Amongst possible reasons are mass transfer and diffusion limitations of the substrate, product or effectors molecules between the bulk phase and the surface, together with changes in protein conformation resulting in altered physical properties of the active site (Engasser and Horvath, 1973; 1974a; 1974b; 1974c; Goldstein, 1976; Taylor and Swaisgood, 1981).
If the enzyme has been chemically attached by covalent linkage, the immobilization reaction itself can also affect activity (Ollis and Datta, 1976; Mosbach, 1980; Bickerstaff, 1980).

In some previous studies in our laboratory, glutamate dehydrogenase was used as a model allosteric enzyme in order to explore the effect of adsorption on the native properties of proteins. This enzyme which showed good affinities for binding to alkyl-substituted adsorbents was found to respond to all positive and negative allosteric modifiers tested, with comparable rates, in free and immobilized forms (Nemat-Gorgani and Karimian, 1982; 1983; 1984; Nemat-Gorgani et al., 1985). This observation suggested the possibility for immobilizing the enzyme in an allosterically-activated conformation and for design strategies regarding tailor-made enzyme carriers.

In the present investigation, this attractive proposition was put to real test and adsorbents were prepared containing positive allosteric effectors for glutamate dehydrogenase and malate dehydrogenase, another well-defined allosteric enzyme. Comparable studies were carried out on immobilized preparations using adsorbents with and without the effectors.

A scanning of the literature on the process of enzyme immobilization would indicate that several factors may cause reduction of the catalytic activities of immobilized enzymes. As for adsorptive immobilization, it has been shown that enzyme activity may be dramatically reduced as a result of the active site being occupied by the ligands in the substituted matrix (Laas, 1975). The data presented here describe methods for preparation of specifically-designed adsorbents, as exemplified by the use of appropriate activators for the two chosen allosteric enzymes. Accordingly, a matrix may be provided which is better suited for immobilization of a given enzyme, with enhanced catalytic efficiency, as compared with use of a matrix of general utility.

\section{CONCLUSION}

In conclusion, results presented in this communication describe a successful approach toward preparation of tailor-made enzyme carriers designed to improve the catalytic potential of enzymes intended for use in an immobilized form.

\section{REFERENCES}

Azari, F. and M. Nemat-Gorgni, 1999. Reversible denaturation of carbonic anhydrase provides a method for its adsorptive immobilization. Biotechnol. Bioeng., 62: 193-199. PMID: 10099529 
Bickerstaff, G.F., 1980. Immobilized enzymes and their use in evaluating subunit interactions. Int. J. Biochem., 11: 201-206. PMID: 7389977

Du Val, G., H.E. Swaisgood and H.R. Horton, 1985. Some kinetic characteristics of immobilized protomers and native dimers of mitochondrial malate dehydrogenase: An examination of the enzyme mechanism. Biochemistry, 24: 2067-2072. DOI: $10.1021 / \mathrm{bi00329a039}$

Engasser, J.M. and C. Horvath, 1973. Effect of internal diffusion in heterogeneous enzyme systems: Evaluation of true kinetic parameters and substrate diffusivity. J. Theor. Biol. 42: 137-155. DOI: 10.1016/0022-5193(73)90153-7

Engasser, J.M. and C. Horvath, 1974a. Inhibition of bound enzymes.III. Diffusion enhanced regulatory effect with substrate inhibition. Biochemistry, 13: 3855-3859. PMID: 4413890

Engasser, J.M. and C. Horvath, 1974b. Antienergistic interaction of chemical and diffusionalinhibition. Biochemistry, 13: 3845-3849. PMID: 4413888

Engasser, J.M. and C. Horvath, 1974c. Inhibition of bound enzymes. II. characterization of inhibition and accumulation. Biochemistry, 13: 3849-3854. PMID: 4413889

Goldstein, L., 1976. Kinetic behavior of immobilized enzyme systems. Methods Enzymol., 44: 397-443. DOI: $10.1016 / \mathrm{s} 0076-6879(76) 44031-4$

Laas, T., 1975. Agar derivatives for chromatography, electrophoresis and gel-bound enzymes. J. Chromatogr., 111: 373-387. PMID: 1117040

Mosbach, K., 1980. The immobilization technique or solid-phase approach as an aid in investigating the interaction of subunits in oligomeric enzymes, notably of dehydrogenases. Biochimie, 62: 623-628. DOI: 10.1016/s0300-9084(80)80109-X

Mullinax, T.R., J.N. Mock, A.J. McEvily and J.H. Harrison, 1982. Regulation of mitochondrial malate dehydrogenase. Evidence for an allosteric citrate-binding site. J. Biol. Chem., 25: 13233-13239. PMID: 7142142
Nemat-Gorgani, M. and K. Karimian and F. Mohanazadeh, 1985. Synthesis, characterization and properties of hexadecyl silica: A novel hydrophobic matrix for proterin immobilizations J. Am. Chem. Soc., 107: 4756- 4759. DOI: 10.1021/ja00302a025

Nemat-Gorgani, M. and K. Karimian, 1982. Non-ionic adsorptive immobilization of proteins to palmitylsubstituted sepharose 4B. Eur. J. Biochem., 123: 601-610. DOI: $10.1111 / \mathrm{j} .1432-$ 1033.1982.tb.6575.x

Nemat-Gorgani, M. and K. Karimian, 1983. Enzyme immobilization on palmityl-sepharose. Biotechnol. Bioeng., 25: 2617-2629. PMID: 18548597

Nemat-Gorgani, M. and K. Karimian, 1984. Interaction of proteins with Triton X-100 substituted sepharose 4B. Biotechnol. Bioeng., 26: 565-572. DOI: 10.1002/bit.260260602

Nemat-Gorgani, M. and K. Karimian, 1986. Use of hexadecyl Fractosil as a hydrophobic carrier for adsorptive immobilization of proteins. Biotechnol. Bioeng., 28: 1037-1043. DOI: 10.1002/bit.260280714

Ollis, D.F. and R. Datta, 1976. Activity correlations between similarly modified soluble and immobilized enzymes. Methods Enzymol., 44: 444-450. PMID: 1021691

Sidelkovskaya, F.P., N.A. Raspevina, A.V. Ignatenko and V.A. Ponomarenko, 1986. Reaction of branched-chain amino acid esters with $\mathrm{N}-(2,3-$ epoxypropyl) pyrrolidone. Russian Chem. Bull., 35: 850-852. DOI: 10.1007/BF00954247

Taylor, J.B. and H.E. Swaisgood, 1981. A unified partition coefficient theory for chromatography, immobilized enzyme kinetics and affinity chromatography. Biotechnol. Bioeng., 23: 1349-1363. DOI: $10.1002 /$ bit.260230614 